\title{
The Feminine Stereotype and Beyond: Role Conflict and Resolution in the Poetics of Marina Tsvetaeva
}

In examining the development of Tsvetaeva's lyric verse, it is possible to discern a recurrent thematic strain: a rejection by the poet of the conventional roles imposed on the individual by society, particularly certain characteristics of the feminine role. I will try to show that Tsvetaeva, in the process of rejecting, via her poetry, this key ingredient in a person's self-concept-namely, the sex role as defined by society-along with a rejection of other limiting social norms, developed images of the self that transcend social roles. ${ }^{1}$ Moreover, the working out of this poetic identity is not continuous but falls into several chronological stages.

In discussing a poet's self, critical method prescribes that a distinction be maintained between the individual and the poetic persona. Without negating this methodological stricture, it is important to keep in mind that for some poets an adequate interpretation requires one to perceive that the persona is an elaborate poetic projection and mythologization of the individual. A well-known case in

1. "Role," "self-concept," and "identity" are used in their commonsense meaning in ordinary discourse, rather than in the more specialized terminological senses established in the fields of psychiatry and sociology. Similarly, when speaking of the evolution of these aspects of an individual in Tsvetaeva's verse, I have made inductive observations about the themes and images in her poetry, rather than proceeding from a particular psychological or sociological model of the life cycle. This is not to say that appropriate models from the social sciences could not be fruitfully applied to explicate the work of some poets. I have found that my literary-critical description of the development of a poetic self-concept in the work of Tsvetaeva has interesting parallels to psychiatric and sociological models as formulated by Erik, H. Erikson, Carl Jung, Erving Goffman, and Ralph H. Turner. I am indebted to Norma Shosid for drawing my attention to Chad Gordon's enlightening study, "Role and Value Development Across the Life Cycle," in Role, ed. J. A. Jackson (Cambridge, 1972), pp. 65-105, which integrates several models of role, identity, and the life cycle.

After completing this paper, I became aware of the studies of the evolution of the poetics of Adrienne Rich and Rich's own observations on the subject contained in the volume Adricme Rich's Poctry: Texts of the Pocms. The Poet and Her Work, Reviezes and Criticism, selected and edited by Barbara Charlesworth Gelpi and Albert Gelpi (New York, 1975). Rich's and Tsvetaeva's "poetics of change," nearly half-a-century and worlds apart, are instructive in their similarities and differences. Another recent study "fusing the making of literature and the formation of personality" is Helene Moglen's psychoanalytically oriented Charlottc Brontë: The Self Conccired (New York, 1976).

The author wishes to thank the Vanderbilt University Research Council and the American Council of Learned Societies for grant support during the preparation of this article. I am grateful to Serge A. Zenkovsky, Susan Ford Wiltshire, Lisa L. Heinrich, and Walter R. Gove for their criticism and encouragement. I am indebted to Simon Karlinsky for the expert and meticulous checking of my translations of the poetic texts, which resulted in a number of corrections and improvements. An earlier version of this article was read at the AATSEEL conference in New York, December 27-29, 1974. 
point is provided by the poetry of Mayakovsky. ${ }^{2}$ In regard to Tsvetaeva, Jane Taubman's assessment is persuasive: "Tsvetaeva . . . is asking us to read her books of verse as a diary of her spiritual life."3 Tsvetaeva herself made explicit statements to this effect. In a letter to Alexander Bakhrakh dated September 5/6, 1923, she wrote: "Vybor slova-eto prezhde vsego vybor i ochishchenie chuvstv, ne vse chuvstva godny, o ver'te, zdes' tozhe nuzhna rabota! Rabota nad slovom -rabota nad soboi."4 And twenty days later, in another letter, she wrote the following: "Budu peresylat' Vam svoi stikhi: preobrazhennuiu-nastoiashchtiu! -zhizn'." 5 Tsvetaeva defines the relationship between her individual and her poetic self as one of selection and transformation. To paraphrase her wordswork in search of the authentic word is work in search of the authentic self. Poetry is life-life transfigured-real life!

Tsvetaeva's letters and prose show her awareness of the limitations of the woman's role and set the stage for its rejection in her verse. The most moving, personal, and explicit account is a description of her mother's life in a letter to V. V. Rozanov (1914), in which she writes:

Mother's youth, like her childhood, was lonely, painful, rebellious, deeply introverted. ... She had a passion for music and enormous talent (never again do I expect to hear anyone play the piano and the guitar like she did), a gift for languages, a brilliant memory, magnificent written style, wrote poetry in Russian and German, painted. ... When she was twenty-two Mother married Father, with the express intention of replacing the mother of his orphaned children-Valeriia, who was eight, and Andrei, who was one. Father was then forty-four years old. She loved him without reservation, but the first two years of marriage were filled with torment about his continuing love for [his first wife] V. D. Ilovaiskaia. "We were wed at the grave," Mother wrote in her diary. She had much difficulty with Valeriia, trying to befriend this eight-year-old girl, who was completely alien to her in temperament, adored her late mother, and rejected "the stepmother." There was much grief. Mother and Father were totally unlike each other. Each had his own heartache. Mother's was music, poetry, yearning; Father's was scholarship. Their lives moved side by side without merging. But they loved each other very much. Mother died [in 1906] at the age of thirty-seven, discontented, unreconciled. . . . Her tormented soul lives on in us [Marina and her sister Anastasiia], but we reveal what she concealed. Her rebellion, her madness, her longing have grown in us to a scream. ${ }^{6}$

In excerpts from Tsvetaeva's diary of 1919, titled "O Germanii" and first published in 1925 in Paris, we find another comment about her mother: "mat'

2. Edward J. Brown, Majakovsky, A Poct in the Revolution (Princeton, N.J., 1973), pp. 6-7.

3. Jane Andelman Taubman, "Tsvetaeva and Akhmatova: Two Female Voices in a Poetic Quartet," Russian Literature Triquarterly, no. 9 (Spring 1974), p. 362.

4. Aleksandr Bakhrakh, "Pis'ma Mariny Tsvetaevoi (Okonchanie)," Mosty (Munich), 6 (1961) : 329.

5. Ibid., p. 334.

6. Marina Tsvetaeva, Ncizdannye pis'ma (Paris, 1972), pp. 28-29. 
ne zhenski vladela roialem! .." (my mother played the piano with a mastery that was not that of a woman). ${ }^{7}$ This brief aside airs the common notion that great artistic skill, in this case the mother's musical prowess and power, is not a normal feminine attribute.

In Tsvetaeva's first volume of verse (Vechernii al'bom, 1910), published when the poet was eighteen, we find a poem with two female protagonists, one of whom advocates breaking the rules. It is significant that not the rebel, but the "realist"- the one who maintains that the rules will be observed -repeatedly has the last word.

\section{Rouge et bleue}

Девочка в красном и девочка в синем

Вместе гуляли в саду.

— "Знаешь, Алина, мы платьице скинем,

Будем купаться в пруду?"

Пальчиком тонким грозя,

Строго ответила девочка в синем:

"Мама сказала-нельвя".

Девушка в красном и девушка в синем

Вечером шли вдоль межи.

—“Хочешь, Алина, все бросим, все кинем,

Хочепь, уедем? Скажи!"

Вздохом сквозь вешний туман

Грустно, ответила девушжа в синем:

"Полно! ведь жизнь-не роман" ...

Женщина в красном и женшина в синем

Шли по аллее вдвоем.

- "Видишь, Алина, мы блекнем, мы стынем,-

Пленницы в счастье своем"...

С полуулыбкой из тьмы

Горько ответила женщина в синем:

"Что же? Ведь женщины мы!"8

(A little girl in red and a little girl in blue were walking together in the park. "Alina, how about taking off our dresses and going for a swim in the pond?" Shaking her thin little finger in a gesture of reproval, the little girl in blue answered sternly, "Mother says we mustn't."

A young woman in red and a young woman in blue were walking in the evening along the edge of a field. "How about it, Alina, let's leave everything and go away? Say you will!" With a sigh through the spring mist the young woman in blue answered sadly, "Don't talk like that! You know life's not a novel. ..."

7. M. I. Tsvetaeva, "O Germanii (Vyderzhki iz dnevnika 1919 goda)," Nesobrannye proizvedeniia (Munich, 1971), p. 469.

8. M. I. Tsvetaeva, Nesobrannye proizvedeniia, p. 15. 
A woman in red and a woman in blue were walking together along a treelined avenue. "Don't you see, Alina, we're fading, we're growing coldprisoners of our happiness. ..." With a half-smile from the darkness the woman in blue answered bitterly, "Are you surprised? We're women!")

In subsequent volumes of Tsvetaeva's early poetry, we find two conflicting identities. One of these is a stylized pose of traditional girl-woman, which is treated with considerable ambivalence. The other identity is that of a proud, potent, gifted creature, which is treated positively. The following two poems from Volshebnyi fonar' (1912) shows this duality most strikingly.

Я только девочка. Мой долг

До брачного венца

Не забывать, что всюду-волк

И помнить: я овца.

Мечтать о замке золотом,

Качать, кружить, трясти

Сначала куглу, а потом

Не куклу, а почти.

В моей руке не быть мечу,

Не зазвенеть струне

Я только девочка,一молчу.

$\mathrm{Ax}$, если бы и мне

Взглянув на звезды знать, что там

И мне звезда зажглась

И улцбаться всем глазам

Не опуская глаз ! 9

(I'm just a girl. It is my duty, until my marriage vows, not to forget that everywhere there lurks a wolf; to remember that I'm a sheep.

To dream about a golden castle; to rock, bounce, shake-first a doll, then not quite a doll, but almost.

My hand will never wield a sword, will never pluck a string. I'm just a girl, I keep silent. Ah, if only I, too, could

Looking up at the stars, know that there a star has been lighted for me, as well, and smile into all eyes without lowering my own!)

The imagery in this poem from the juvenile period consists in the main of a series of stylized cliches. The world seen as proper to the girl speaker of the poem is one of dreams about a golden castle. Her destiny is to rock a doll in 
mechanical fashion (kachat', krushit', triasti-rock, bounce, shake), and even the later role of motherhood has as its object merely an almost-doll. The outside world is likewise given expression by means of conventional imagery. Its dangers are represented by the symbolic wolf. The unattainable (male) roles are those of a'arrior, metonymically represented by a sword, and of musician or bard, represented by a stringed instrmment. The behavior appropriate to the girl speaker is to be submissive-she is a sheep and she is silent. The speaker of the poem accepts her fate, but longs for a star of her own in the firmament-perhaps a star of achievement and fulfillment. The conclusion of the poem represents the longed-for freedom as permissibility to smile at others without being required to lower one's gaze.

In the next poem, written in the same period, the speaker rejects the role proper for a woman:

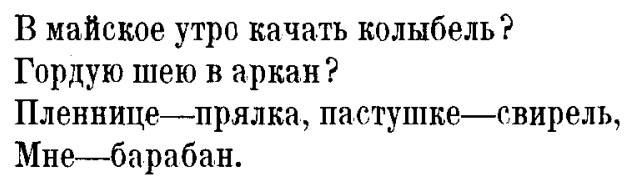

Женская доля меня не влечет:

Скуки боюсь, а не ран!

Все мне дарует,一и власть и почет

Мой барабан!

Солнышко встало, деревья в цвету . . .

Сколько невиданных стран!

Всякую грусть убивай на лету,

Бей, барабан!

Быть барабанщиком! Всех впереди!

Все остальное-обман!

Что покоряет сердца на пути,

Как барабан ?º

(On a May morning rock a cradle? Put my proud neck in a rope halter? The captive has her spinning wheel, the shepherdess her pipe, I have my drum.

A woman's lot does not attract me: I fear boredom, not wounds! Everything is given me-power and honor-by my drum!

The sun has risen, the trees are in bloom. . How many unknown lands there are! Let every sorrow be put to flight. Sound, my drum!

To be a drummer! At the head of the band! Everything else is sham! What else can win hearts along the way like my drum?) priadka.

10. Ibid., p. 46. In this edition, the word prialka in the first stanza is misprinted as 
In this period and subsequently, until approximately 1920, we continue to encounter in Tsvetaeva's verse the use of imagery and diction drawn from the feminine world or referring to feminine stereotypes. It is important to make a distinction between the notions of world and stereotype. The former refers to an actual way of life, that is, to experience. Stereotype commonly refers to a mental image or characterization of what a particular group of people is like or should be like. Stereotypes are formed on the basis of real phenomena, but are fragmentary, exaggerated, or generalistic impressions about those phenomena. It is probably the case that stereotypical impressions are produced not by the individuals to whom they refer but by members of other groups, for example, by whites about blacks (or vice versa) or by men about women (or vice versa). However, once the stereotype is established in the culture, it may come to be accepted by the referent group itself. We have already seen some examples of stereotypical imagery in the poem "Ia tol'ko devochka." The following stanza. from another poem written in the same period contains additional references to feminine stereotypes:

\section{Медленный дождик идет и идет, Золото мочит кудрей. \\ Девочка тихо стоит у дверей, Девочка ждет. ${ }^{11}$}

(The slow rain keeps falling, it dampens the gold of the curls. The girl stands quietly at the door, the girl waits.)

Here "the gold of the curls" is a stereotypical emblem of femininity. In the next stanza we see the girl waiting and wondering whether the boy will come: Mal'chik, idi zhe: begi zhe skorei:/Devochka zhdet! This image of the female waiting passively for the male to act is also a stereotypical one, although the language is not specifically so.

One of the feminine images of the earliest period is not stereotypical but concerns an aspect of practical life. This is the reference to the woman's pinnedup coiffure, the pricheska, that is contrasted to the loosely hanging hair worn by young girls (examples of both may be seen in the photographs in Anastasiia Tsvetaeva's memoir ${ }^{12}$ ). The pricheska appears in a poem in the volume $V e$ chernii al'bom (1910):

\section{Наша мама не любит тяжелой прически,--} Только время и шпильки терять !13

(Our mother doesn't like the heavy hairdo-you just lose time and hairpins!)

11. Ibid., p. 34.

12. Anastasiia Tsvetaeva, Vospominaniia (Moscow, 1971).

13. M. I. Tsvetaeva, Nesobrannye proizvedeniia, p. 11. 
It reappears in Volshebnyi fonar', an emblem of the conventional restrictions placed on the adult (woman), as opposed to the freedom of the child:

0 , для чего я выросла большая?

Спасенья нет!

Еще вчера в зеленые березки

Я убегала, вольная, с утра.

Еще вчера палила без прически,

Eще вчера!

Что впереди? Какая неудача?

Во всем обман и, ах, на всем запрет 14 $^{14}$

(Oh, why have I grown up? There's no escaping! Only yesterday I could run off in the morning, free, to the green birches. Only yesterday I could play without a hairdo. Only yesterday! . . What lies ahead? What ill fortune? Everything harbors deception and, alas, everything is forbidden!)

In the collection $V$ ersty $I$, which was published in 1922 but which contains poetry written in 1916, the treatment of stereotypical women's roles is shifted to new ground. First, instead of the object imagery of the juvenile period-such as the negative (restrictive) emblemata of dolls, dresses, and hairdos, or the positive, liberating emblem of the drum-the imagery is predominantly drawn from the animate world. Second, instead of uttering explicit pronouncements like "zhenskaia dolia menia ne vlechet," the poetic persona is shown negating conventional social expectations implicitly by means of nonconventional identities in a variety of imaginative scenarios. This continues to be Tsvetaeva's modus operandi in the $1930 \mathrm{~s}$. In the poems in Versty $I$, the speaker maintains a feminine identity, indeed emphasizes it, but it is a frankly Romantic one, drawn from folklore and endowed with heroic, legendary, or magic attributes.

In this period, the role conflict is no longer the merely anticipated one of the juvenile period. Tsvetaeva is now twenty-four years old, established in the roles she has questioned (her marriage to Sergei Efron took place in early 1912 and their daughter Ariadna was born in December of the same year), and also irrevocably committed to poetry. The dual creative power of motherhood and of verbal art is represented as an antithesis of light and darkness in a strikingly joyous poem written on the eve of the Feast of the Annunciation (March 25), in which the speaker prays in the Cathedral of the Annunciation.

-Благословен плод чрева

Твоего, Дева

Милая!

14. Ibid., p. 31 . 
Светла, горяча

Зажжена свеча.

К Солнцу-Матери,

Затерянная в тени,

Воззываю и я, радуясь:

Матерь-матери

Сохрани

Дочку голубоглазую!

В светлой мудрости

Просвети, направь

По утерянному пути-

Блага.

Дай здоровья ей,

$\kappa$ ивголовью еи

Отлетевпего от меня

Приставь-Ангела.

От словесной храни-пышности

Чтоб не вышла как $₫-$-хищницей

Чернокнижницей. 15

("Blessed is the fruit of thy womb, Virgin dear?" . . . Bright, hot is the lighted candle.

To the Sun-Mother, I, lost in the shadows also call, rejoicing: "Mother, for a mother preserve my blue-eyed daughter! Illumine her with bright wisdom; guide her in the lost path of goodness. Grant her health; at the head of her bed set the Angel who has flown from me. Guard her against verbal splendors so she doesn't turn out like me-a predator, a practitioner of black magic.")

As a mother, the speaker shares the joy of Mary and addresses her in a tone of intimacy and trust. However, her prayer is uttered only on behalf of her child. She herself does not emerge into the light that emanates from the "Sun-Mother," remaining "in the shadows." Moreover, she has "lost the way of goodness," has been abandoned by her guardian angel, and has been rendered, through the excesses of her art, a "predator" and a "magician." She asks that her datighter be spared such a fate and instead be "illumined by bright wisdom." (Of course, one should avoid the mistake of identifying life and art too closely. Only a few years later Tsvetaeva delighted in her daughter's literary precocity.)

The speaker's association with sin and magic is a recurrent motif in this volume, revealing a continuing ambivalence about the social and personal definition of the self. The ambivalence, however, is largely an implicit one deducible from the attributes assumed by the personae of the poems. The one explicit state-

15. Marina Tsvetaeva, Versty (Moscow, 1922), pp. 26-27. 
ment about the roles of women appears in a poem written in April. Using folk diction and imagery characteristic of this period, the speaker promises to her interlocutor that, should she choose to be his lover, she will be a lover of legendary accomplishments-but she will not undertake any of the conventional women's roles. She will be neither wet nurse, nor wife, nor widow, nor maiden waiting for her intended.

\section{Коли милым назову-не соскучишься ! Богородицей-слыву-Троеручицей : Одной-крепости крушу, друга--тамотка, Третьей по морю пишу-рыбам грамотку.}

Только в мамки-не гожусь-в колыбельщицы !

Коль похожа на жену-где повойник мой?

Коль похожа на вдову-где покойник мой?

Коли суженого жду-где бессонница?

Царь-Девицею живу-безваконницей $!^{16}$

(If I should love you-you will never tire of it! I am renowned as a motherof-god-the three-handed one: with one hand, I smite down fortresses, the second is far away, with the third I write on waves-a letter to the fishes. Only as a wet nurse I won't do-a cradle rocker!

If I seem to be a wife-where's my wife's kerchief? If I seem to be a widow -where's my deceased? If I'm waiting for my betrothed-where's my sleeplessness? No, I'm the Tsar-Maiden-I live outside the law!)

In a poem written in 1918, a year after the birth of her second child, Tsvetaeva again expresses her ambivalence toward social convention, on the one hand, and her individual affinities, on the other. With barely concealed irony, the speaker presents herself as performing the functions imposed by society and a personal sense of duty, but in conclusion affirms her love for the antisocial. The images are stylized in folk idiom.

Белье на речке полощу, Два цветика своих ращу.

Ударит колокол-крещусь, Посадят голодом-Пощусь.

Душа и волосы-как шелк.

Дороже жизни-добрый толк.

16. Ibid., p. 56 . 
Я свято соблюдаю долг.

一Но я люблю вас-вор и волк $!^{17}$

(I rinse the laundry in the river; I raise my two little flowers. When the bell tolls, I cross myself; when they confine me without food, I fast. My soul and hair are smooth as silk. More precious than life to me is a good reputation. I solemnly observe my duty. But-I love you, thief and wolf!)

It is relevant at this point to interpose some observations on those of Tsvetaeva's long poems and dramas in verse that have a bearing on her thematic rejection of sex-role stereotypes. Two of the poemy, Tsar'-Devitsa and $\mathrm{Na}$ krasnom kone, and one of the verse dramas, Prikliuchenie, feature, in some form, a reversal of sex roles. ${ }^{18}$ Chronologically Tsar'-Devitsa (written in 1920) and Prikliuchenie (written probably in 191919) are intermediate between the poems of Versty $I$ and Remeslo, the latter containing poetry written in 1921-22. The second long poem, $\mathrm{Na}$ krasnom kone, was written in January 1921 and, as pointed out by Karlinsky, ${ }^{20}$ is stylistically related to the poems of Remeslo.

Tsar'-Devitsa is an epic poem based on tales collected by Afanas'ev. The title heroine is a warrior-maiden of unwomanly size, strength, and martial prowess. She is first introduced in a hyperbolic vision:

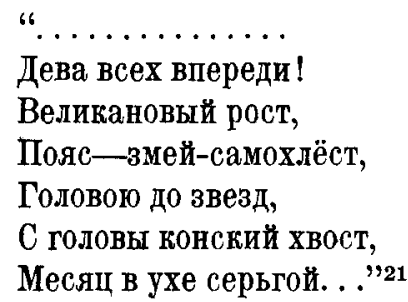

(The maiden [rides] at the head! Her stature is that of a giant, her girdle -a coiled serpent, her head reaches the stars, from her head [waves] a mare's tail, the moon [hangs] in her ear for an earring....)

17. Marina Tsvetaeva, Izbrannye proizvedeniia (Moscow, 1965), p. 129. See also the pejoratively phrased stereotypical notion that philosophizing about abstract matters is as unnatural in a woman as singing would be for a fish in an April 1918 poem in Marina Tsvetaeva, Lebedinyi stan, 2nd ed. (Paris, 1922), p. 51.

18. See Simon Karlinsky, Marina Cvetaeva: Her Life and Art (Berkeley, 1966), p. 224. The play Prikliuchenie is based on the memoirs of Casanova. Karlinsky describes how Tsvetaeva "changed and adapted ... Casanova's characterisations, particularly that of [the heroine] Henriette" (ibid., p. 249). Karlinsky concludes by saying: "This ambiguous, almost hermaphroditic character is the most frank embodiment of Cvetaeva's indistinct dream of love and intimacy based on personal worth, which would exceed the limitations of one particular sex" (ibid., p. 249). He adds: "The same tendency can be discerned in the cycles 'Uchenik' in Remeslo, 'Brat'ja' in Psixeja, the poem 'Klinok' in Poslc Rossii, and in some of the episodes of 'Povest' o Sonechke.'" Considerations of space preclude discussion of the latter, but it provides revealing autobiographical material about Tsvetaeva's capacity for infatuation with young women as well as men.

19. Karlinsky, Cvetaeva, p. 248.

20. Ibid., p. 211.

21. M. Tsvetaeva, Izbrannye proisvedeniia, p. 346. 
In a dialogue with her niania she denies any desire for suitors:

Мой жених-мой меч пресветлый, Меч мой сабельный, веселый :

Мне цругих дружков-не надо !22

(My bridegroom is my bright sword, my saber-like joyous sword: I need no other companion!)

She addresses her army in a thunderous voice:

"Здорово, стан сильномогучий!"-

Гремит громоподобный глас. ${ }^{23}$

("Hail, my mighty-powerful troops," thunders the thunderlike voice.)

Her army greets her by likening her to Michael, the warrior angel. Her step is heavy:

Как по сходням взошла

Стопудовой пято́й, ${ }^{24}$

(As she mounted the steps with a two-ton step ...)

She falls in love with a young prince who is her very antithesis:

Я, мальчишка узкогрудый, С бранным бытом незнаком.

Гусли, гусли-самогуды

Мне-единственный закон! ${ }^{25}$

(I'm a narrow-chested boy, unfamiliar with martial ways. The singing psaltery is the only law I know!)

When the Tsar-Maiden first sees the young prince, she lovingly compares his delicate, ring-bedecked hand with her own massive, swarthy, ringless "paw":

Равняет руку с своен.

"Как суха корочка!

Как есть-без мякиша!

Твоя-то-перышко,

Моя-то-лапища!

22. Ibid., p. 353.

23. Ibid., p. 356 .

24. Ibid., p. 358; see also p. 362: Pod voennoi da pod veskoi stopoi/chut' ne tresnul ves' chelnok skorlupoi.

25. Ibid., p. 354. 
И каждый пальчик-то

Как царь закованный!

А моя-черная

Да бесперстнёвая!

Твоя-ковры расшивать,

Моя-дубы корчевать."26

(She compares his hand with hers: "Like a dry little breadcrust without any soft part! Yours is a little feather, mine is a large paw. And each of your fingers is like a tsar in armor, while my hand is swarthy and ringless. Yours is for embroidering tapestries, mine for uprooting oak stumps.")

Similarly, his hair is fine and silky, while hers is coarse like horsehair:

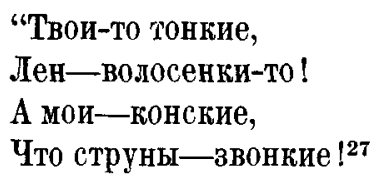

(Your hair is fine like flax! Mine-like horsehair, like resonant strings!)

I owe to Anya M. Kroth the observation that the Tsar-Maiden and the Tsarevich are two exemplars of androgyny, she of the strong masculine woman, he of the gentle, feminine man, each possessing characteristics of both sexes. ${ }^{28}$ Tsvetaeva develops, at some length, the idea that in these two lovely androgynous creatures the conventional opposition of male to female is confounded:

-Гляжу, гляжу, и невдомек:

Девица-где, и где дружок?

Ты расплетись, вере́вьице !

Где юноша? Где девица?

То́т юноша?-лицом кругла, То́т юноша?-рука мала:

Одной косы две плеточки, Две девицы-красоточки.

Да больно вид-то их таков, А ну-ка двое пареньков?

26. Ibid., p. 363 .

27. Ibid., p. 364.

28. Anya M. Kroth, paper presented at the Seventh National Convention of the AAASS, Atlanta, October 8-11, 1975. 
То́т девица ?-глядит насквовь !

То́т девица?-коленки вровь!

Одной руки суставчики, Два юноши-красавчика. 29

( $\mathrm{I}$ look and am in a quandary: which is the maiden and which her sweetheart? Untwine, rope! Which is the young man, which the young girl? Is that one the youth? - no, she's too round of face, is that one the youth?no, the hand is too small: They're like two strands of one braid, two pretty young girls. [On the other hand], their appearance is, well-maybe it's two young fellows? Is that one the girl?-no, he/she looks straight through you. Is that one the girl? - - no, the knees are apart! They are like two joints of one hand-two handsome young men.)

Since neither protagonist quite fits the masculine or the feminine stereotype, the author invites readers to suspend rational categories and draw their own conclusions about the Tsar-Maiden and the Tsarevich. ${ }^{30}$ The author's own preferred solution seems to be that the whole issue of sexual identity is an illusion. Might not the Tsarevich and the Tsar-Maiden ultimately represent a meeting of two angelic beings, she asks hopefully:

\section{A ну́ как зорче поглядим- \\ И вовсе всё обман один, \\ И вовсе над туманом-дым, Над херувимом-серафим ?31}

(But if we take a keener look-why it's all a deception, smoke [wafting] above the mist-is it a seraph [bending] over a cherub?)

Tsvetaeva's second long poem, $N a$ krasnom kone, is a lyrical narrative about the arduous making of a poet. The heroine, who is also the first-person narrator, avers that she has been guided not by a (feminine) Muse but by her own poetic (masculine) Genius, who is personified as a knight on a red steed. The narrative is developed by means of the folkloric motif of the quest, during which the heroine undergoes three temptations. Through the intervention of the Genius, she renounces, in turn, her childish affections for treasured objects and her attempt to give herself to the crucified Christ. In the course of the third temptation she experiences the pain and rage of unrequited love and rejects her womanliness to become, herself, a mounted warrior. She is vanquished by a mysterious ray of light that penetrates her heart, whereupon the Genius acknowledges her as his chosen one and extracts a vow of fidelity:

29. M. Tsvetaeva, Izbrannye proizvedeniia, pp. 364-65.

30. Ibid., p. 365 .

31. Ibid. 
И пепот: такой я тебя желал!

И рокот: такой я тебя избрал,

Дитя моей страсти--сестра-брат-

Невеста во льду—лат!

Моя и ничья-до конца лет.

Я, руки вовдев: свет!

-Пребудешь? Не будешь ничья,-—нет?

Я, рану зажав: нет. ${ }^{32}$

(And the whisper: "[Now] you are as I desired you!" And the murmur: "[Now] you are as I elected you, Child of my passion-[my] sister-[my] brother-[my] bride in the ice of armor.

My own and no one's-till the end of years." I with arms raised: "[My] light!" "You will remain so? You will not be anyone's? No one's?" I, clutching my wound: "No.") ${ }^{33}$

The transition into what may be called the "middle period" occurs in the year 1920, and this period lasts through approximately 1927 . There is not only an observable change in the imagery, but also a general poetic evolution and maturing on many levels. Biographically the entry into the middle period is marked by the death of her young daughter Irina of starvation in a state foster home ${ }^{34}$ by emigration; by reunion with her husband, Sergei Efron, after five years of separation; and by her passage into her fourth decade of life. The poetic product of the period includes the poems in Remeslo and finds its culmination in Posle Rossii. Additional poems of the period were collected for the first time in the 1961 and 1965 Soviet editions of her works. The middle period of Tsvetaeva's oeuvre is, of course, extremely complex. I will only point out the most salient themes that seem to represent the poet's continuing rejection of the conventional woman's role and her continuing personal and artistic individuation.

The recurring image of the self as a disembodied (poetic) voice first appears in a poem written in April 1920:

Ко мне не ревнуют жены:

Я-голос и взгляд. ${ }^{35}$

(Wives aren't jealous of me: I'm [just] a voice and a glance.)

32. Ibid., p. 441. The imagery of armor harks back to the poem "Ruan" written in 1917, whose speaker has a prevision of reenacting the martyrdom of Joan of Arc; M. I. Tsvetaeva, Ncisdannoe: Stikhi, teatr, proza (Paris, 1976), p. 110.

33. Translation by Simon Karlinsky, Cvetaeva, p. 209. The final "no" is to be read as an assent to the knight's query.

34. Readers who are misled by the topic of this paper into thinking that Tsvetaeva lacked maternal affection can find a corrective in the poem "Dve ruki," written on the occasion of Irina Efron's death; see M. Tsvetaeva, Izbrannye proizvedeniia, pp. 155-56.

35. Ibid., p. 157. 
Next we note the gradual disappearance of the conventional feminine imagery, especially the external, girlish accouterments referring to the poetic persona. In a poem in May 1920 Tsvetaeva still uses the image of a pink dress moved by the wind as an emblem of capriciousness in the self:

Я не танцую,-без моей вины

Пошло волнами розовое платье. ${ }^{36}$

(I am not dancing-it is not my fault that the pink dress is moving in waves.)

The windblown dress is held down by the speaker and the octave concludes:

0, если б Прихоть я сдержать могла,

Как разволнованное ветром платье $!^{37}$

(Oh, if I could control Whim the way I can control my dress blown [or: excited] by the wind!)

Similarly, in a poem written just a day earlier - the well-known "Kto sozdan iz kamnia, kto sozdan iz gliny"- the speaker refers to her curls (kudri) as a sign that she in no way can be considered "the salt of the earth." However, in a poem written three months later, in August 1920, we find that the pretty face (lichiko) and the play of passions are ascribed by the speaker not to herself but to others:

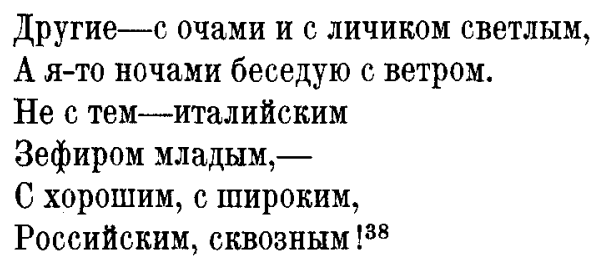

(Others dally with bright eyes and a pretty face, but $I$ in the night converse with the wind. Not that one-the Italian one, the young zephyr-no, with a good, sweeping Russian gale!)

The poem is concluded with the words:

Нет, с нами Эол обращается круто.

-Небось, не растаешь! Одна, мол, семья!-

Как будто и вправду-не женщина я! ${ }^{30}$

(Yes, Aeolus treats my kind roughly. [He says:] "Don't worry, you won't

36. Ibid., p. 162.

37. Ibid., p. 163.

38. Ibid., p. 165 .

39. Ibid. 
melt! You're all the same flesh and blood!" As if in truth I were not a woman!)

The last phrase-perhaps I'm really not a woman-sounds an important note that is elaborated in several ways in subsequent poems. In Remeslo Tsvetaeva employs, as in the long poems discussed above, a reversal of sexes, notably in the cycle "Uchenik," where the speaker desires to be a young male disciple and martyr:

Быть мальчиком твоим светлоголовым, -0 , через все века! -

За пыльным пурпуром твоим брести в суровом Плаще ученика. ${ }^{40}$

(To be your fair-haired boy-O, through the ages! To walk behind your dusty purple in a coarse pupil's cloak.)

In the cycle "Georgii,"41 dedicated to her husband, St. George the Dragon-slayer is described as modest, shy, humble, and gentle, with long beautiful eyelashes and the eyes of a deer. His saddle and spear are referred to using diminutives (sedletso, kop'etso). He pales and weeps after his victory and refuses the maiden that is to have been his reward for slaying the dragon.

Remeslo contains one of the first allusions to the Amazons, the proud strong warrior women with whom the poet feels a kinship. ${ }^{42}$ The entire poem is quoted here because it offers yet another example of Tsvetaeva's complex poetic attitude toward the feminine:

Грудь женская! Души застывший вздох,-

Суть женская! Волна, всегда врасплох

Застигнутая-и всегда врасплох

Вас застигающая-видит Бог!

Презренных и презрительных утех

Игралище.-Грудь женская! Доспех

Уступчивын!-Я думаю о тех...

06 одногрудых тех,-—подругах тех! ..43

40. Marina Tsvetaeva, Remeslo (Berlin, 1923), p. 7. An early (1913) poem anticipates the sex-reversal as well as the paradoxical imagery of gentle and strong femininity (see M. Tsvetaeva, Isbrannye proisvedeniia, p. 59).

41. M. Tsvetaeva, Remeslo, pp. 39-50.

42. An earlier allusion appears in a 1915 poem (M. I. Tsvetaeva, Neizdannoe, p. 89). A later one appears in Poslc Rossii, in the poem "Dvoe," discussed in the next paragraph. Tsvetaeva's attraction to the image of the Amazon is especially evident in the rhapsodic description of Antiope, the Amazon mother of Hippolytus, in Fcdra, discussed below, p. 252 and footnote 67.

43. M. Tsvetaeva, Rcmeslo, p. 86. 
(A woman's breast! A frozen sigh of the soul, a woman's essence! A wave that is always taken unawares and always takes you unawares-as God is my witness!

A playground for disdained and disdainful pleasures. A woman's breast!-A yielding armor/weapon! I'm thinking of them-Those one-breasted onesthose friends! ...)

Although the concluding three hemistichs of the poem are suggestive rather than explicit, I submit that Tsvetaeva may be sensing a parallel between the Amazons, who sacrificed part of their essential femininity (by amputating their left breast) to the requirements of their craft-archery in warfare-and her own sacrifice of the merely feminine self to the craft of poetry.

In Posle Rossii, Tsvetaeva continues to develop the theme of an equality between a man and a woman, although there are only a chosen few-Siegfried and Brunhilde, Achilles and the Amazon queen Penthesileia, and Tsvetaeva herself and her poetic equal, Boris Pasternak. ${ }^{44}$ In July 1924, in a poem addressed to Pasternak, she writes:

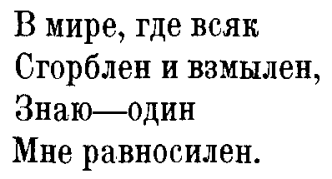

$\ldots \ldots \ldots \ldots \ldots \ldots \ldots$

В мире, где всё-

Плесень и плющ,

Знаю: один

Ты-равносущ

Мне. ${ }^{45}$

(In a world where everyone is bent and in a lather [like a horse], I knowthere is one of equal strength with Me.

In a world where everything is mold and ivy, I know-you alone are equal in being to $\mathrm{Me}$.)

No longer does the poet claim that the world bars her from self-affirmation, as in the poems of the juvenile period. Her problem, indeed, appears to be the opposite-she can find virtually no one who is her equal in range and power.

The poetic speaker of this period repeatedly identifies herself with heroic women, and is concerned with her soul and her vocation as a poet. Of the several

44. M. I. Tsvetaeva, Posle Rossii (Paris, 1928), p. 129.

45. Ibid., p. 130. This poetic cycle is discussed by Jane Taubman, "Between Letter and Lyric: The Epistolary-Poetic Friendships of Marina Tsvetaeva" (Ph.D. diss., Yale University, 1972), pp. 98-102. 
mythological figures that exerted a fascination on Tsvetaeva, a telling one is the sibyl, the subject of a poem written in $1921^{46}$ and of the cycle of three poems in Posle Rossii $(1922,1923) .{ }^{47}$ In the context of the present discussion, the sibyl can be seen as representing the agelessness and selflessness of the poetic (vatic) self, which is a passive receptacle of a god. A parallel is drawn between the sibyl, as the mythological oracle of Apollo, and Mary, who served as the receptacle of the Incarnation of Christ the Word (voice). Mortality is overcome, and a cosmic dimension gained, but at the expense of human life $\mathrm{e}^{48}$ :

Сивилла: вещая ! Сивилла: свод !

Так Благовещенье свершилось в тот

Час не стареющий, так в седость трав

Бренная девственность, пещерой став

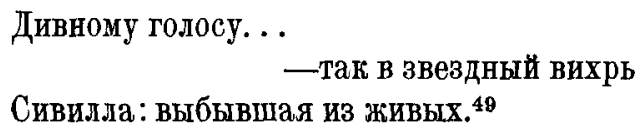

(The sibyl is prophetic! The sibyl is a vault! Thus the Annunciation came to pass in that

Never-aging hour, thus into the grayness of grasses (merged) mortal virginity, becoming a cave

For the marvelous voice ... -thus into the astral whirlwind (traveled) the sibyl, who had left the ranks of the living.)

In contrast to the sibylline cosmic though lifeless identity, the affirmation of unconventional but earthly womanhood reaches its culmination in this period. In a poem written in June 1922 the poet says:

Здравствуй! Не стрела, не камень:

Я!一живейшая из жен:

Жизнь. Обеими руками

В твой невыспавшийся сон..$^{50}$

(Hail/hello! It is not an arrow or a stone: it is I, the most alive of women: Life! With both hands [I plunge] into your unfinished sleep.)

46. M. Tsvetaeva, Remeslo, p. 63. In the second part of "Povest' o Sonechke," Tsvetaeva quotes a 1919 poem in which she speaks of herself as the "ancient Sibyl." Her explanation of the association is that she, at that time, felt infinitely older than the friends whom she describes in the memoir (M. I. Tsvetaeva, Neisdannoe, p. 286).

47. M. I. Tsvetaeva, Posle Rossii, pp. 24-27.

48. In a later poem (ibid., p. 132) Tsvetaeva defines woman as a mysterious keeper of the future.

49. Ibid., pp. 24-25.

50. Ibid., p: 14. 
Here the speaker contends that she is a living woman-and more. Being a woman, she is not limited by the feminine gender of the noun $z h i z n^{\prime}$-as was Pasternak's speaker in his apostrophe to life, "Sestra moia-zhizn'!" ("My sister-life!") - to claiming merely a metaphorical blood kinship with life. The female persona of Tsvetaeva's poem can claim to be life itself. ${ }^{51}$

A major poem of the mature period, which continues the theme of rejection of the conventional woman's role, is "Poezd zhizni," written in October 1923. In this poem, the train is a metaphor of violent death. The poet no longer is rejecting stereotypes but the actual, to her unacceptable, minutiae that dominate the lives of women. While it can be argued that men suffer from byt no less than do women - a convincing poetic case was made by Mayakovsky - no man, but many a woman finds her private hell defined by just the realia enumerated in the excerpt quoted below:

0, как естественно в третий класс

Из душности дамских комнат!

Где от котлет разогретых, шек

0стывших. ..-Нельзя ли дальше, Душа? Хотя бы в фонарный стокОт әтой фатальной фальши:

\author{
Папильоток, пеленок, \\ Щипцов каленых, \\ Волос паленых, \\ Чепцов, клеенок, \\ 0 -де-ко-лонов \\ Семейных, пвейных \\ Счастий (klein wenig!) \\ Взят ли кофенин? \\ Сушек, подушек, матрон, нянь, \\ Душности бонн, бань.
}

Не хочу в этом коробе женских тел

Ждать смертного часа!

Я хочу, чтобы поезд и пил и пел:

Смерть-тоже вне класса! $!^{52}$

51. In the anthologized "Popytka revnosti," as in "Poezd zhizni," the speaker is exempted from being an ordinary woman. The drive against the conventional is not without some qualified reversals. In an interesting poem written June 26, 1922 (M. Tsvetaeva, Izbrannye proizvedeniia, pp. 197-98), a few weeks or days before Tsvetaeva's anticipated reunion with her husband, we find a pledge of humble earthly service to an earthly lover by a speaker who claims to have shared the properties of the divine. The speaker's erstwhile divinity is expressed in Biblical imagery. The image of the earthly service that is promised is also taken from related desert culture-she will be a brazier providing warmth.

52. M. Tsvetaeva, Posle Rossii, pp. 123-24. 
(O how natural to go into a third-class carriage from the staleness of parlors and kitchens!

Where warmed-up cutlets and cooled-down cheeks . . Let's get away from it, my soul! Even a gutter is better than this deadly falsity:

Of curling papers, diapers, hot curling irons, singed hair, bonnets, oilcloths, toilet waters, of family happiness and dressmaking joys (klein wenig!), "Did you pack the coffeepot?," of biscuits, pillows, matrons, nannies, stuffiness of governesses, baths.

I don't want to wait for my hour of death in this hamper of female flesh! I want the train to drink and sing: death, too, is classless.)

Here, as in other poems of this period, there is no longer a duality between the conventional and the individual zrithin the poetic persona. The conventional is ascribed to others or rejected out of hand. In a poem written in November 1924, Tsvetaeva uses related imagery to go even further, rejecting her very body as an unacceptable limiting part of the self.

Пела, как стрелы.

Тело?

Мне нету дела! 53

(I sang like arrows. The body? None of my business!)

This poem brings us to the most prominent emblem representing the poet's freedom from convention-the image of the soul-which is joyously celebrated in a poem of February 1923:

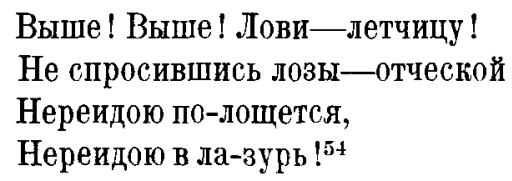

(Higher! Higher! Catch-the flying one! Without asking permission of the paternal vine, she splashes like a Nereid, a Nereid [diving] into the azure!)

The poem concludes by envisioning the soul dancing above corpses, dolls, and other inauthentic realia of $b y t$, as a fiery, seraphic, true being:

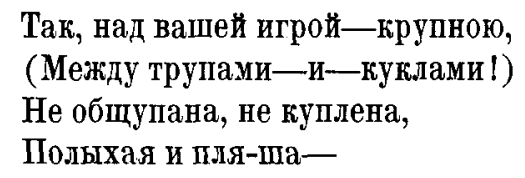

53. Ibid., p. 134. It is important not to interpret this image as an expression of a dislike of the physical. It is rather a statement of the poet's creative and spiritual freedom; see also the remarkable poem, "Zhiv, a ne umer," ibid., pp. 147-48.

54. Ibid., p. 52. 


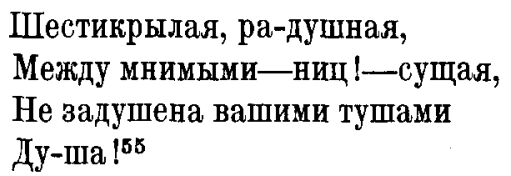

(Thus, above your games for high stakes (among corpses and dolls!), not pinched and poked, not bought, blazing and dancing-six-winged, hospitable, among imaginary beings - fall prostrate! - a true being, not suffocated by your carcasses-the Soul!)

The series of poems occasioned by Tsvetaeva's profound emotional involvement with Boris Pasternak ${ }^{56}$ is important in the definition of the self in the middle period. In this poetry of longing and passion, an identity is established between the persona and certain tragic heroines who have suffered unrequited love or tragic separation-Ariadne, Phaedra, Ophelia, Eurydice. The ultimate love is represented by the passionate devotion of Mary of Magdala and the compassionate response of Jesus, which are played out in the cycle of three poems titled "Magdalina." As suggested by Karlinsky, the use of mythological, literary, and scriptural tradition to express a private anguish imbues the poems with a sense of universality and gives them a dimension larger than life. ${ }^{57}$

The two dramatic poems titled Ariadna (originally Tezei) and Fedra ${ }^{58}$ are part of the middle period, both chronologically and stylistically. These dramas, with their heroic female figures (the chaste and manly goddess Artemis, the passionate Amazon warrior Antiope, and the tragic Phaedra) reflect a wide range of attitudes toward women: disparagement (by Minos of his daughter Ariadne ${ }^{58}$ ), disdain or disgust (by the misogynist Hippolytus for Phaedra ${ }^{60}$ and other women ${ }^{61}$ ), celebration (of Artemis by the chorus of young hunters ${ }^{62}$ and of Phaedra after her death by a chorus of women ${ }^{63}$ ), adoring admiration (of Hippolytus's mother, the Amazon, by Hippolytus ${ }^{64}$ and his old servant ${ }^{65}$ ), and

55. Ibid., pp. 52-53.

56. See Jane Andelman Taubman, "Marina Tsvetaeva and Boris Pasternak: Toward the History of a Friendship," Russian Litcrature Triquarterly, no. 1/2 (1971-72), p. 312. See also Olga Raevsky Hughes, "Pasternak and Cvetaeva: History of a Friendship," Books Abroad, 44 (Spring 1970): 218-21; and Olga R. Hughes, The Poctic World of Boris Pasternak (Princeton, 1974), pp. 105-10.

57. Karlinsky, Cuctacva, p. 196.

58. Ariadna was begun in October 1923 and completed in October of 1924. The planning of the trilogy and the beginning of Ariadna chronologically overlap the writing of the poems occasioned by the departure of Pasternak for the Soviet Union (for example, "Fedra," "Provoda," and "Ariadna," March/April 1923; "Rasshchelina," "Zanaves," and "Stroitel'nitsa strun," June 1923; "Brozhu, ne dom zhe plotnichat'," October 1923). All of these, including the poems about Ophelia and Hamlet and Eurydice and Orpheus, also written in this period, share a common theme-the tragic separation of a woman from the man she loves. The story of Ariadne represents abandonment-of Phaedra, rejection-by the beloved.

59. M. Tsvetaeva, Izbrannyc proizvedeniia, p. 647.

60. M. I. Tsvetaeva, Nesobrannye proizvedeniia, pp. 397 and 440.

61. Ibid., p. 432.

62. Ibid., p. 392.

63. Ibid., p. 450.

64. Ibid., p. 440.

65. Ibid., pp. $429-30$. 
empathy (by the poet, for the impotent lust of Phaedra's old nurse ${ }^{86}$ ). Strictly speaking, these representations of conventional and unconventional attitudes toward women cannot be viewed as attempts to define the poetic self in the same way as can the lyric poetry, since they are uttered by and about third-person dramatic characters. Yet the emotional intensity with which the dramatis personae are made to speak, and the extraordinary vividness with which their experiences are presented, particularly in Fedra, betray an identification of the poet with her characters. ${ }^{\text {B }}$ ?

One of the most important aspects of the definition of poetic identity in the verse of Tsvetaeva's middle period is, undoubtedly, the image of the self as poet. This is a large subject deserving separate study. I shall refer here only to the brilliant cycle of three poems titled "Poety," written in April 1923, which celebrates the anticonventional role of poets. In the first poem, poets are said to violate every expectation, such as the law of gravity and normal causality. In the second poem they are paradoxically termed outcasts who dare to rival the gods. In the last poem of the cycle, the speaker begins by describing herself as being blind and a stepchild in a world of the sighted who have fathers (Chto zhe mne delat', sleptsu $i$ pasynku,/V mire gde kazhdyi $i$ otch $i$ zriach ....). She reverses herself after the first stanza and concludes the poem by claiming to be a singer (bard) and the first-born in a gray world of weights and measures:

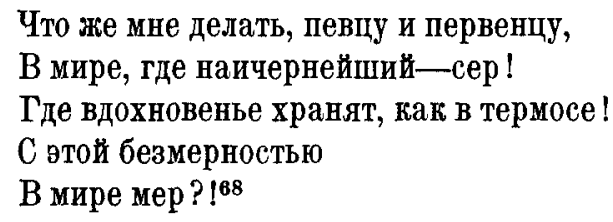

(What shall I do, a singer and first-born in a world where the blackest is gray! Where inspiration is stored as in a thermos bottle! With my limitlessness in a world of [weights and] measures?!)

This poem anticipates Tsvetaeva's last period in that her rejection of stereotypical roles is no longer formulated with reference to the limitations of feminine roles. Instead, it is presented as an antithesis between poetry and byt, a radical alienation of the poet from social convention.

Examination of the poetry of Tsvetaeva's last poetic period, after the publication of Posle Rossii in 1928, shows that the issue of the feminine role is no longer explicitly raised. I would argue, however, that it has not been simply abandoned. Rather, it is in some respects integrated into a vision of the self-as-

66. Ibid., p. 459.

67. See especially the panegyric description of Hippolytus's mother, the Amazon queen Antiope, in battle (M. I. Tsvetaeva, Nesobrannye proizicdeniia, pp. 429-30). The sensual imagery of the Amazon's physical and emotional oneness with her bow, its string, and its arrows are surely without compare in world literature as a representation of the heroic woman. Equally remarkable is the stark physical imagery in the speech of Phaedra's old nurse (ibid., p. 459). It is a vivid first-person account of the sexual desire of an unlovable old woman.

68. M. Tsvetaeva, Posle Rossii, p. 79. 
poet. I will support this argument by examining two poems from the period. They were written in 1935 and 1934, respectively, a dark time for Marina Tsvetaeva the individual, marked by unremitting poverty and by political, social, and literary ostracism in Paris émigré circles.

In the first poem, the poet is seen as one who accepts complete self-renunciation by subordinating the self to the poetic vocation. The first stanza reads:

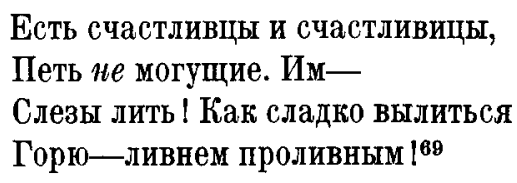

(There are fortunate men and women who can't sing. It is their lot to weep. How sweet it is to pour out one's grief in a gushing torrent.)

The text continues, in part:

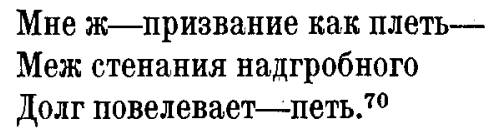

(But to me my calling is like a scourge-amidst the wailing at the tomb, duty orders-sing!)

The poem is concluded by a telling couplet, which is a paraphrase of the Biblical "the Lord giveth, the Lord taketh away":

Ибо раз голос тебе, пюэт, Дан, остальное-взято. ${ }^{71}$

(For if a voice is given to you, poet, everything else is taken away.)

It is significant that, in this deeply felt, personal poem, reference to the first person is made only once, in the oblique case. This poem is not egocentric. The question of the woman's role is not raised. The poetic gift and the poetic sacrifice of self transcend the realm of social roles. Indeed, the persona claims a kinship between herself and two (male) poets of antiquity-Orpheus and the Biblical David.

In the second poem, poetry and the poet's life blood are presented as an identity:

69. M. Tsvetaeva, Izbrannye proizvedeniia, p. 309.

70. Ibid.

71. Ibid., p. 310. 


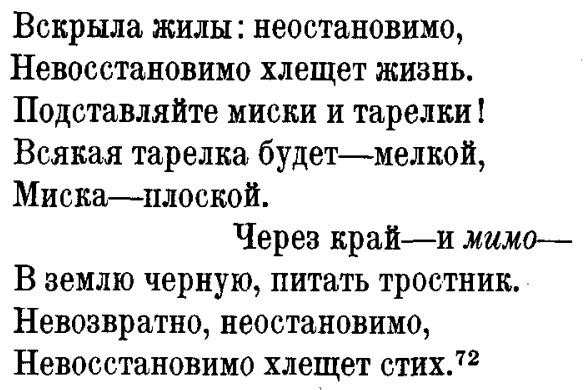

(I have opened my veins: unrestrainably, unrestorably life gushes out. Go ahead, bring bowls and plates: every plate will be too shallow, every bowl too flat. Spilling out and over-into the black earth, to feed the reeds. Irretrievably, unrestrainably, unrestorably verse gushes out.)

In this powerful short poem, the references to the woman's world are not obvious, but I believe they are present and are integrated into the very compact statement of the text. The poet ironically invites the world to receive and store her lifeblood-poetry-in mundane domestic utensils (bowls and plates), which are emblems of the shallowness of byt drawn from the domain of women. The attempt to contain poetry in such pedestrian vessels is bound to fail. The contrasting, symbolically appropriate "receptacle" for living creation is the black (that is, fertile) earth. It is limitless in its capacity to absorb the abundant poetic nourishment offered by the poet and it, like poetry, is organic, not man-made, and thus a viable medium for furthering natural life and growth.

Reference to the persona in this poem is again minimal, occurring only in the past tense feminine verb form that is the first word of the poem-vskryla. It is important, however, that of the two key words constituting the terms of the equation of the poem-life and verse-one is feminine and the other masculine: zhizn' and stikh. I suggest that this is yet another instance of Tsvetaeva's many poetic attempts to remove the barrier between the masculine and the feminine, in this case on the grammatical-hence subconscious-level. I believe it is especially significant that the function of the poet's gift of life is defined as feeding - pitat - the quintessential feminine and, in the Judaeo-Christian tradition, a sacramental function. Even as the mundane, conventional paraphernalia of the byt of food preparation (miski, tarelki) are rejected, so is the life-giving, nurturing, self-sacrificing role of the poet embraced.

It has been shown that Tsvetaeva, in her early poetry, took as one of her themes the limiting aspects of the woman's social role and questioned this role as applied to the poet's self. In this period, the woman's role was poetically represented by using images of the feminine stereotype. In $V$ ersty, the persona assumed masks of Romantic, anticonventional women; and in Tsar'-Devitsa and Prikliuchenie, as well as in some of the short poems of the early twenties, key protagonists were represented with the masculine and feminine attributes reversed or confounded. In Tsvetaeva's mature period, represented by the collections Remeslo and Posle Rossii, the poet voiced outright rejection of actual components

72. Ibid., p. 303. An uncanny twin of Tsvetaeva's image appears in Sylvia Plath's lines: The blood jet is poetry/There is no stopping it (Aricl [New York, 1966], p. 82). 
of the woman's role, rather than of stereotypical images. The rejection was accompanied by the creation of a multiplicity of poetic representations and selfrepresentations. These range from the emblems of the strong, proud woman (for example, the Amazon), to the vatic voice (the sibyl), and to the free transcendent being (the soul). In this and the subsequent period, the poetic voice and poetic creation were affirmed as the essence of life.

One wonders what meaning Tsvetaeva's quest for a self-determined identity had for her contemporaries. Some of the critical animus against her was surely provoked by her loud, exclamatory poetic voice and her proclamations of power and attonomy, rather than by the avowed disapproval of her poetic modernity and her near-blasphemous political individualism. Today, thirty-five years after Tsvetaeva's death, in the context of the ongoing reaction by women and men against social stereotypes, the passionate existential rebellion embodied in her art is both familiar and meaningful. 